\title{
Ekstrak Etanol Kulit Buah Naga Menurunkan Indikasi Neoplasia Mammae Tikus Putih Berdasarkan Histopatologi dan Inhibitor Siklooksigenase-2
}

\author{
(DRAGON FRUIT ETHANOL EXTRACT REDUCES INDICATIONS OF WHITE RAT \\ NEOPLASIA BASED ON HISTOPATHOLOGY AND CYCLOOXYGENASE-2 INHIBITORS)
}

\author{
Muhammad Thohawi Elziyad Purnama ${ }^{1}$, Ragil Angga Prastiya ${ }^{2}$, \\ Faisal Fikri ${ }^{3}$, Amung Logam Saputro ${ }^{4}$, Bodhi Agustono ${ }^{5}$ \\ ${ }^{1}$ Laboratorium Anatomi, Departemen Anatomi Veteriner, \\ ${ }^{2}$ Laboratorium Reproduksi, Departemen Reproduksi Veteriner, \\ ${ }^{3}$ Laboratorium Fisiologi, Departemen Kedokteran Dasar Veteriner, \\ ${ }^{4}$ Laboratorium Klinik, Departemen Klinik Veteriner, \\ ${ }^{5}$ Laboratorium Produksi Ternak, Departemen Peternakan, \\ Fakultas Kedokteran Hewan, Universitas Airlangga \\ Kampus-C Unair Jln. Mulyorejo, Surabaya, \\ Jawa Timur, Indonesia, 60115 \\ Telp. (031) 5993016, Fax. (031) 5993015 \\ Email : thohawi@fkh.unair.ac.id
}

\begin{abstract}
ABSTRAK
Kanker disebabkan proliferasi sel yang tidak terkendali dan dipicu oleh perubahan informasi sel yang mengatur pertumbuhan. Potensi kanker dari setiap sel berbeda sehingga banyak prevalensi penderita kanker seperti kanker endometrium, kanker kelenjar limfe, kanker paru-paru, kanker kulit, dan kanker kelenjar mammae. Penelitian ini bertujuan untuk menguji potensi ekstrak etanol kulit buah naga terhadap tikus putih (Rattus norvegicus) yang dipapar 7,12-dimethylbenz(á)antrasena (DMBA) pada kelenjar mammae berdasarkan aspek gambaran histopatologi dan intensitas penanda siklooksigenase-2 (Cox-2). Penelitian ini menggunakan 20 ekor tikus putih yang dibagi menjadi lima kelompok perlakuan dengan masing-masing empat ulangan, yakni K+ tanpa dipapar DMBA dan ekstrak; K- dipapar DMBA; P1 dipapar DMBA dan ekstrak dosis $10 \mathrm{mg} / \mathrm{kg}$ BB; P2 dipapar DMBA dan ekstrak dosis $15 \mathrm{mg} / \mathrm{kg}$ BB; P3 dipapar DMBA dan ekstrak dosis $20 \mathrm{mg} / \mathrm{kg}$ BB. Injeksi DMBA diberikan selama dua kali seminggu selama lima minggu melalui intrakutan dan ekstrak diberikan setiap hari dengan sonde lambung selama 14 hari. Data hasil skoring dan perhitungan dianalisis dengan sidik ragam dan dilanjutkan dengan uji Duncan. Hasil penelitian menunjukkan bahwa skor gambaran histopatologi terjadi penurunan yang signifikan pada P3 dan penurunan intensitas warna Cox-2 yang signifikan pada P1, P2 dan P3. Simpulan penelitian ini adalah ekstrak etanol kulit buah naga dapat menurunkan indikasi neoplasia kelenjar mammae tikus putih ( $R$. norvegicus) berdasarkan gambaran histopatologi dan inhibitor Cox- 2 .
\end{abstract}

Kata-kata kunci: antosianin; buah naga; kelenjar mammae; neoplasia; siklooksigenase-2

\begin{abstract}
Cancer caused uncontrolled cell proliferation and triggered by changes on cell information that regulate growth function. Each cell has different potential so many cancer prevalence such as endometrial cancer, lymph node cancer, lung cancer, skin and mammary gland cancer. The aims of this study were to assess the potential of dragon fruit skin ethanolic extract on white rats (Rattus norvegicus) exposed 7,12Dimethylbenz(á)antrasena (DMBA) on mammary gland based on histopathological features and cyclooxygenase-2 (Cox-2) intensity. This study were used 20 of rats randomly divided into five group and each groups consisted of four rats, i.e: K+ weren't treated DMBA and extract; K- were treated with DMBA;
\end{abstract}


P1 were treated with DMBA and extract $10 \mathrm{mg} / \mathrm{kg} \mathrm{BW}$; P2 were treated with DMBA and extract $15 \mathrm{mg} / \mathrm{kg}$ BW; P3 were treated with DMBA and extract $20 \mathrm{mg} / \mathrm{kg}$ BW. The DMBA was given by intra dermal injection during twice a week for five weeks and the extracts with gastric tube everyday till 14 days. The data was analyzed by Anova test and continued with Duncan test. The result showed that the histopathological features were decrease significantly on P3. The variables of Cox-2 intensity were decrease significantly on P1, P2 and P3. Conclusion of this study was ethanol extract of dragon fruit skin can decrease neoplastic indication of mammary gland on white rats (R. norvegicus) based on histopathological features and Cox-2 inhibitors.

Keywords: anthocyanin; dragon fruit; mammary gland; neoplasia; cyclooxygenase-2

\section{PENDAHULUAN}

Kanker merupakan penyakit yang disebabkan oleh proliferasi sel multiseluler sehingga terjadi perubahan sifat sel yang tidak terkendali. Penyebab kanker dapat dipicu oleh pola hidup yang tidak sehat dan faktor genetik yang menyebabkan perubahan informasi sel berupa pengaturan pertumbuhan sel. Penurunan fungsi apoptosis sebagai pengatur proliferasi sel dapat semakin meningkatkan potensi perkembangan sel kanker yang masif (Warshawsky dan Landolph, 2006).

Adams et al. (2010) melaporkan hasil survei di Britania Raya bahwa kanker pada anjing menjadi salah satu kasus yang sering dilaporkan dengan angka prevalensi mencapai 15-16\%. Pemeriksaan pascamati terhadap 2000 ekor anjing menunjukkan angka mortalitas mencapai $27-45 \%$ di antaranya menyerang anjing usia di atas 10 tahun. Data prevalensi kanker pada anjing maupun hewan kesayangan di Indonesia belum banyak dilaporkan. Namun, berdasarkan kejadian kematian anjing, beberapa disebabkan oleh kanker endometrium, kanker kelenjar limfe, kanker paru-paru, kanker kulit dan kanker kelenjar mammae. Kanker pada sel mast juga tercatat menjadi kasus terbaru dengan angka prevalensi 7-21\% yang telah terdiagnosis dengan angka mortalitas masih rendah sekitar 0,1\% (Dobson, 2013).

Penggunaan antiestrogen secara parsial dapat memicu terjadinya penuaan dini karena penurunan kadar estrogen secara drastis sehingga mengurangi fisiologi tubuh dalam membantu perkembangan sel. Penggunaan antiestrogen yang bersifat akumulatif juga menghentikan daya potensi perkembangan sel yang sifatnya tidak membawa kanker. Efek endogenus reseptor hormon estrogen (ER), progesteron (PR), prolaktin (PRL-R), dan Epidermal Growth Factors (EGF-R) yang berlebihan dapat berdampak pada regulasi Growth Hormon (GH). Hiperestrogenisme menimbulkan efek negatif pada peningkatan produksi GH di hipofisis. Hormon GH dapat imunoreaktif pada pertumbuhan sel epitel kelenjar mammae. Peningkatan sel epitel kelenjar mammae merupakan indikasi adanya metastasis, hiperkromatisasi dan mitosis nukleus (Misdorp, 2002).

Enzim siklooksigenase-2 (Cox-2) merupakan pemicu radikal bebas yang mendukung dan berpotensi dalam meningkatkan jaringan bersifat neoplasia. Peningkatan Cox-2 berhubungan dengan proses proliferasi sel dan angiogenesis pada kasus tumor yang sangat progresif. Enzim Cox-2 memegang kendali utama dalam meningkatkan metastasis sel kanker yang biasa ditemukan pada kasus kanker kelenjar mammae dan kanker kolon (Costa et al., 2002).

Pada kelenjar mammae yang mengalami adenoma kompleks, teramati struktur tubulus dipenuhi jaringan myxoid yang terdiri dari proliferasi sel-sel myoepitel. Sementara itu pada adenokarsinoma teramati adanya desmoplasia jaringan ikat fibrosa, emboli pembuluh limfe, dan nekrosis pada sel-sel tubulus ginjal (van Dijk et al., 2008).

Buah naga (Hylocereus undatus) merupakan buah kaktus yang banyak dikembangkan masyarakat di Indonesia. Buah naga yang berwarna merah mengandung antioksidan terutama antosianin dan betasianin yang berfungsi sebagai imunomodulator dan senyawa protektif karsinogenik. Kulit buah naga juga banyak mengandung asam organik, protein, dan mineral seperti kalium, magnesium, kalsium, zat besi dan vitamin C (Stinzing et al., 2004; Le Bellec et al., 2006; Evi dan Amrun, 2007). Kulit buah naga telah diteliti sebagai antioksidan alami karena mengandung kaempferol, quercetin dan isorhamnetin (Yi et al., 2011). Penelitian ini bertujuan untuk mengetahui potensi ekstrak etanol kulit buah naga yang dapat menurunkan indikasi neoplasia kelenjar mammae pada tikus putih berdasarkan variabel gambaran histopatologi dan hambatan siklooksigenase- 2 . 


\section{METODE PENELITIAN}

\section{Preparasi Ekstrak Kulit Buah Naga}

Sebanyak $5 \mathrm{~kg}$ kulit buah naga merah yang telah matang dikeringkan dengan oven (Binder ${ }^{\mathbb{R}}$ FED Series) pada suhu $100^{\circ} \mathrm{C}$ selama dua hari. Kulit yang telah kering digerus menjadi serbuk dan selanjutnya direndam dengan etanol 96\% selama dua hari untuk dilakukan proses maserasi. Larutan maserasi disaring dengan kertas saring Whatman dan hasil saringannya ditampung untuk selanjutnya dilakukan proses penguapan hingga pekat menggunakan rotary evaporator $\left(\mathrm{IKA}^{\circledR} \mathrm{RV}-10\right)$.

\section{Preparasi Hewan Model,}

Tikus putih galur wistar sebanyak 20 ekor diadaptasikan selama tujuh hari dipastikan sehat serta dalam fase yang sama melalui swab mukosa vagina. Senyawa induksi kanker mammae yang digunakan adalah 7,12-dimethylbenz $(\alpha)$ antrasena (DMBA) dengan pelarut minyak jagung. Dosis DMBA yang diberikan $15 \mathrm{mg}$ secara injeksi intrakutan di sekitar kelenjar mammae sebanyak dua kali seminggu selama lima minggu. Palpasi daerah injeksi pada kelenjar mammae dilakukan setiap hari untuk mengamati pertumbuhan sel kanker.

Tikus putih dibagi menjadi lima kelompok perlakuan dengan empat ulangan pada masingmasing perlakuan. $\mathrm{K}+$ : tidak diinduksi DMBA dan ekstrak kulit buah naga; K-: hanya diinduksi DMBA; P1: diinduksi DMBA dan ekstrak kulit buah naga dosis $10 \mathrm{mg} / \mathrm{kg} \mathrm{BB}$; P2: diinduksi DMBA dan ekstrak kulit buah naga dosis $15 \mathrm{mg} / \mathrm{kg}$ BB; P3: diinduksi DMBA dan ekstrak kulit buah naga dosis $20 \mathrm{mg} / \mathrm{kg}$ BB. Ekstrak kulit buah naga yang digunakan sesuai dengan dosis uji menurut Yang et al., (2011) yakni 10, 15, dan $20 \mathrm{mg} / \mathrm{kg} \mathrm{BB}$.

Tanda kanker diketahui setelah teraba masa keras dengan palpasi dan secara makroskopik adanya penonjolan dengan batas tak jelas pada kelenjar mammae. Selanjutnya diberi ekstrak kulit buah naga secara per oral dengan sonde lambung setiap hari sekali selama 14 hari sesuai dosis yang telah ditentukan. Pada hari ke-15 (sehari setelah pemberian ekstrak kulit buah naga terakhir), tikus putih dieutanasia secara inhalasi dikorbankan nyawanya dengan cara menggunakan kloroform. Setelah itu difiksasi dan diseksi untuk mendapatkan bagian kelenjar mammae. Selanjutnya dilakukan pembuatan sediaan histopatologi dan pewarnaan imuno-histokimia terhadap kelenjar mammae.
Teknik Pembuatan Preparat Histopatologi

Organ kelenjar mammae difiksasi dalam larutan formalin $10 \%$ selama 48 jam. Selanjutnya dilakukan dehidrasi dengan alkohol konsentrasi bertingkat 70, 80 dan 96\%. Proses kliring dengan larutan xylol dilanjutkan pembuatan blok paraffin suhu $60^{\circ} \mathrm{C}$. Selanjutnya proses seksi dengan mikrotom dan hasil potongan diletakkan dalam penangas air/water bath sebelum dilekatkan pada object glass. Selanjutnya dilakukan deparafinasi dengan xylol dan kliring dengan alkohol konsentrasi menurun. Sediaan kemudian diwarnai dengan hematoksilin eosin dan ditutup dengan entellan sebelum cover glass.

Pengamatan terhadap gambaran histopatologi kelenjar mammae mengacu pada metode Misdorp (2002). Aspek formasi tubulus skor 1 (susunan lengkap), skor 2 (sedang), skor 3 (tidak ada tubulus); aspek hiperkromatisasi dan mitosis nukleus skor 1 (terjadi pada satu nukleus), skor 2 (terjadi pada dua hingga tiga nukleus), skor 3 (terjadi lebih dari tiga nukleus); aspek morfologi nukleus skor 1 (uniform), skor 2 (pleomorfis), skor 3 (semua nukleus pleomorfis). Total skor dari ketiga aspek dapat ditentukan tingkat keganasan kanker yakni 3-5 Grade I, 6-7 Grade II dan 8-9 Grade III. Pengamatan dilakukan secara mikroskopis dengan metode kualitatif yang mengamati masing-masing sepuluh lapang pandang dalam satu ulangan. Pengamatan menggunakan mikroskop cahaya (Nikon ${ }^{\circledR}$ E-200) perbesaran 1000 kali.

\section{Teknik Immunohistokimia}

Organ kelenjar mammae difiksasi dalam larutan formalin $10 \%$ selama 48 jam. Selanjutnya dilakukan dehidrasi dengan alkohol konsentrasi bertingkat 70, 80 dan 96\%. Proses kliring dengan PBS dengan $\mathrm{pH}$ 7,4 sebanyak tiga kali masing-masing selama 5 menit. Selanjutnya direndam dalam hidrogen peroksidase $3 \%$ selama 10 menit dan $1 \%$ BSA dalam PBS selama 10 menit. Ditambahkan antibodi primer anti Cox-2 biotin labeled selama 1 jam pada suhu ruang. Selanjutnya dicuci dalam PBS pH 7,4 sebanyak tiga kali masingmasing selama 5 menit. Selanjutnya ditambahkan Streptavidin-Horse Radish Peroksidase (SA-HRP) selama 60 menit pada suhu ruangan dan dicuci dalam PBS $\mathrm{pH} 7,4$. Selanjutnya ditambahkan kromogen 3,3Diaminbenzidine tetrahydrochloride (DAB) selama 20 menit dan dicuci dengan aquades selama 5 menit. Sediaan kemudian diwarnai 
dengan counterstain metilen biru dan ditutup dengan entellan sebelum cover glass.

Pengamatan terhadap ekspresi Cox-2 dilakukan secara mikroskopis dengan metode skoring Sinuhaji et al. (2013). , yakni intensitas kecoklatan lapang pandang 0\% dengan skor 0 berarti normal, intensitas kecoklatan lapang pandang 0-25\% dengan skor 1 berarti rendah, intensitas kecoklatan lapang pandang 25-50\% dengan skor 2 berarti sedang, dan intensitas kecoklatan lapang pandang $>50 \%$ dengan skor 3 berarti tinggi. Skoring dilakukan sebanyak sepuluh lapang pandang dalam satu ulangan dengan perbesaran 1000 kali.

\section{Analisis Statistika}

Rataan skoring histopatologi kelenjar mammae dan Cox-2 dianggap sebagai data yang didapat dan diuji normalitas dengan uji Kolmogorov-Smirnov. Data yang terdistribusi normal, dilakukan analisis parametrik menggunakan sidik ragam atau Analysis of variance satu arah dan hasil yang berbeda nyata $(\mathrm{p}<0,05)$ dilanjutkan dengan uji Duncan. Data yang tidak terdistribusi normal, dilakukan analisis non parametrik menggunakan uji Kruskal-Wallis dan data yang berbeda nyata $(p<0,05)$ dilanjutkan dengan uji Mann-Whitney. Seluruh proses analisis dikerjakan dengan program SPSS v23.

\section{HASIL DAN PEMBAHASAN}

Hasil rataan (mean) dan standart deviasi (SD) gambaran histopatologi dan Cox-2 organ kelenjar mammae disajikan seperti pada Tabel 1. Pada Tabel 1 diketahui bahwa skoring sediaan histopatologi kelenjar mammae menunjukkan perbedaan yang nyata $(\mathrm{p}<0,05)$ antara $\mathrm{K}$ dengan $\mathrm{K}+$ dan $\mathrm{P} 3$ yang berarti bahwa dosis 20 $\mathrm{mg} / \mathrm{kg}$ BB merupakan dosis minimal yang dapat menurunkan skor neoplasia kelenjar mammae.

Skoring intensitas warna penanda Cox-2 menunjukkan perbedaan yang nyata $(\mathrm{p}<0,05)$ antara $\mathrm{K}$ - dengan $\mathrm{K}+, \mathrm{P} 1, \mathrm{P} 2$ dan $\mathrm{P} 3$ yang berarti bahwa dosis $10 \mathrm{mg} / \mathrm{kg}$ BB merupakan dosis minimal yang dapat menurunkan intensitas penanda Cox-2. Gambaran histopatologi dan Cox-2 organ kelenjar mammae disajikan pada Gambar 1 dan Gambar 2.

Menurut van Dijk et al. (2008) neoplasia kelenjar mammae tampilannya berifat mikrosistik, solid dan mikroglanduler. Kelenjar mammae yang mengalami adenokarsinoma tampak jaringan ikat fibrosa dan nekrosis pada sel epitel tubulus asini serta emboli saluran limfe. Senyawa DMBA dapat menghambat pengaturan pembelahan sel yang diperankan oleh Cyclin Dependen Kinase (CDK). Inaktivasi CDK dapat menurunkan performans protein retinoblastoma $(\mathrm{pRb})$ yang bertindak sebagai pengatur proliferasi sel dan akan merusak mekanisme transkripsi DNA. Kerusakan transkripsi DNA dari protein $\mathrm{pRb}$, dapat menimbulkan mutasi dari gen $\mathrm{Rb}$ sehingga proliferasi sel pada siklus replikasi sel (G1Sintesis) tidak dapat terkendali (Price dan Wilson, 2006).

Kerusakan DNA juga dapat dipicu oleh DMBA dengan cara menekan gen p53. Gen p53 merupakan penyandi utama dalam memelihara genom untuk mengkontrol sel melalui kode gen p21 dan gen Growth Arrest and DNA Damage45 (GADD45). Kode gen p21 dan GADD45 berfungsi untuk melangsungkan siklus sel dan perbaikan DNA sehingga apabila kedua gen ini tidak menerima stimulasi dari p53 maka terjadi kehilangan kendali proses intrasel (Kusewitt, 2012).

Perubahan regulasi GH dapat dipengaruhi oleh efek endogenus pada reseptor ER, PR, PRLR, dan EGF-R. Hiperestrogenisme menimbulkan efek pada peningkatan produksi GH di hipofisis. Peningkatan GH dapat berakibat imunoreaktif dengan memicu pertumbuhan sel epitel kelenjar mammae. Peningkatan sel epitel kelenjar

Tabel 1. Rataan (mean) dan standar deviasi pengamatan histopatologi dan Cox-2 organ kelenjar mammae

\begin{tabular}{ccc}
\hline $\mathrm{P}$ & Histopatologi $(\mathrm{x} \pm \mathrm{SD})$ & Cox-2 $(\mathrm{x} \pm \mathrm{SD})$ \\
\hline $\mathrm{K}+$ & $3,00^{\mathrm{a}} \pm 0,000$ & $0,25^{\mathrm{a}} \pm 0,191$ \\
$\mathrm{~K}-$ & $5,85^{\mathrm{c}} \pm 1,193$ & $3,70^{\mathrm{b}} \pm 1,669$ \\
$\mathrm{P} 1$ & $5,55^{\mathrm{c}} \pm 0,823$ & $1,55^{\mathrm{a}} \pm 0,755$ \\
$\mathrm{P} 2$ & $5,00^{\mathrm{bc}} \pm 0,489$ & $0,75^{\mathrm{a}} \pm 0,772$ \\
$\mathrm{P} 3$ & $4,30^{\mathrm{b}} \pm 0,258$ & $1,05^{\mathrm{a}} \pm 0,574$ \\
\hline
\end{tabular}

Keterangan : $\mathrm{K}+$ : tanpa diinduksi DMBA dan ekstrak kulit buah naga;

K- : diinduksi DMBA;

P1 : diinduksi DMBA dan ekstrak dosis $10 \mathrm{mg} / \mathrm{kg} \mathrm{BB}$;

P2 : diinduksi DMBA dan ekstrak dosis $15 \mathrm{mg} / \mathrm{kg} \mathrm{BB}$;

P3 : diinduksi DMBA dan ekstrak dosis $20 \mathrm{mg} / \mathrm{kg}$ BB.

Superskrip yang berbeda pada kolom yang sama menunjukkan adanya perbedaan yang nyata antar perlakuan $(p<0,05)$ 


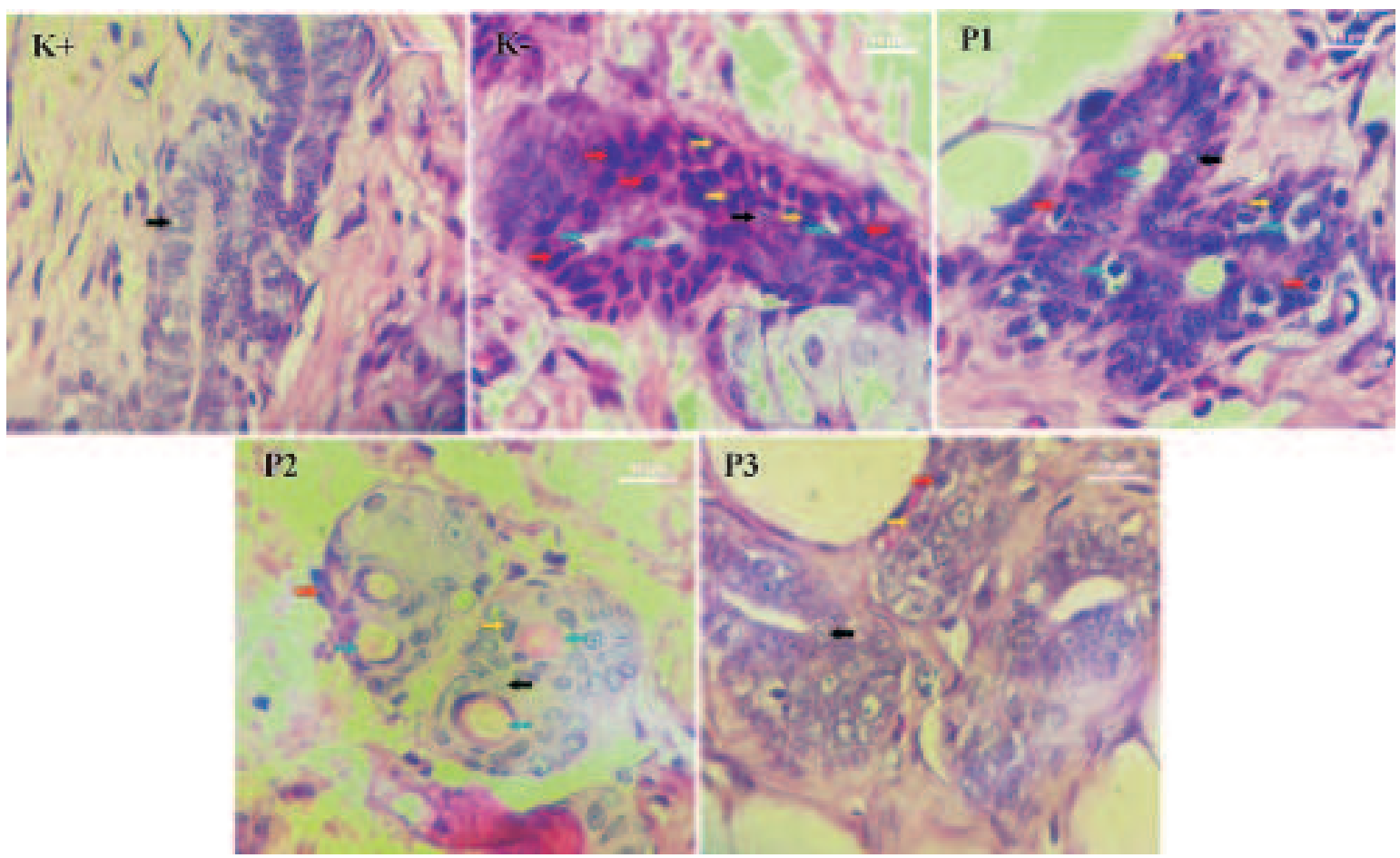

Gambar 1. Gambaran histopatologi neoplasia kelenjar mammae. Tanda panah $(\rightarrow)$ sel normal; $(\rightarrow$ )hiperkromatisasi; $(\rightarrow$ mitosis nucleus; dan $(\rightarrow)$ malformasi dari tubulus asini. Perlakuan K- berbeda nyata $(\mathrm{p}<0,05)$ dengan $\mathrm{K}+, \mathrm{P} 2$ dan P3. (Pewarnaan HE; Perbesaran 1000 kali).

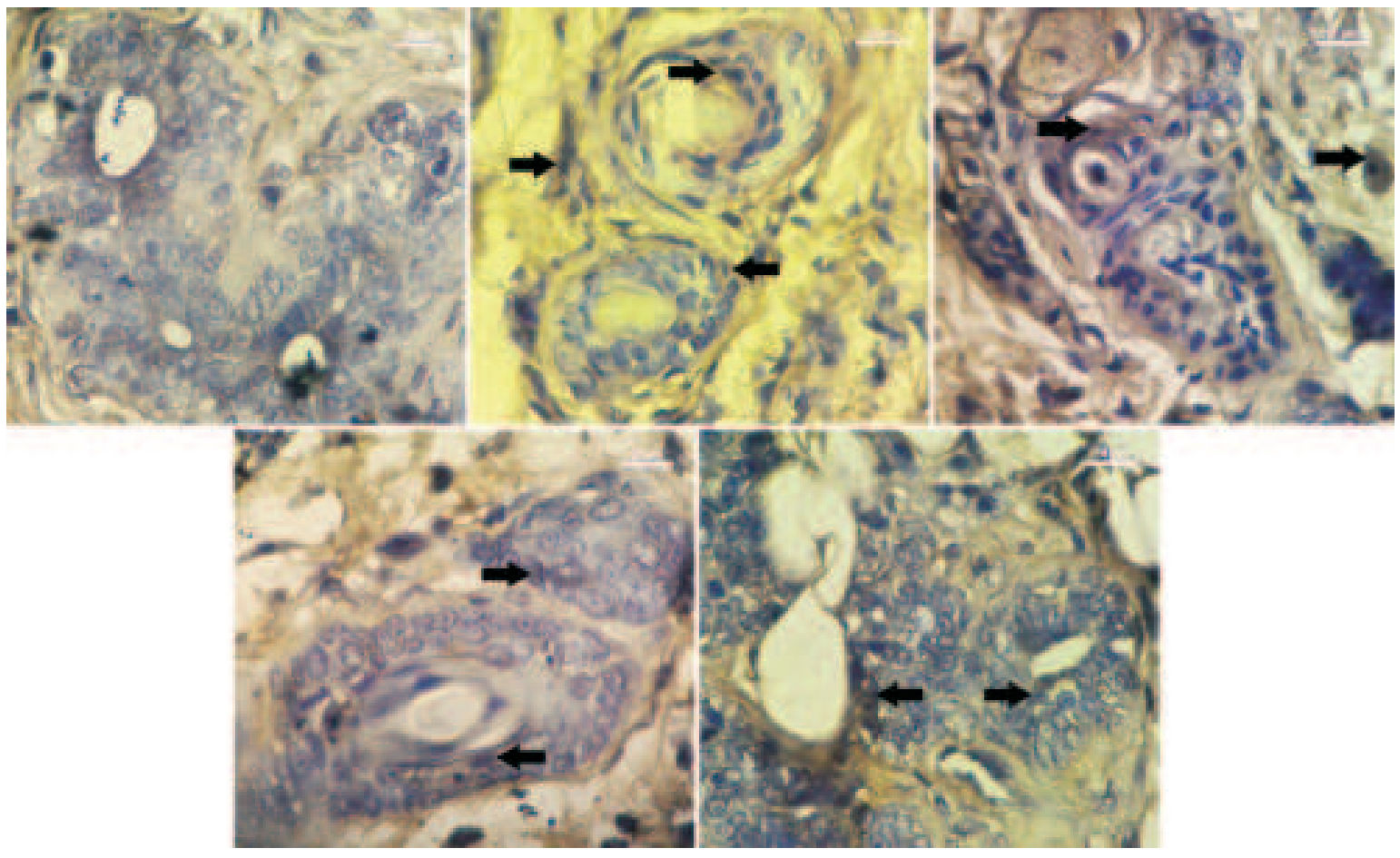

Gambar 2. Tanda panah menunjukkan perbedaan intensitas warna kecoklatan pada sel epitel tubulus asini mengindikasikan ekspresi siklooksigenase-2 (Cox-2) kelenjar mammae. Perlakuan K- berbeda nyata $(\mathrm{p}<0,05)$ dengan $\mathrm{K}+$, P1, P2 dan P3. (Pewarnaan IHK; Perbesaran 1000 kali). 
mammae merupakan indikasi adanya metastasis serta hiperkromatisasi dan mitosis nukleus (Misdorp, 2002; Purnama dan Samik, 2014).

Dog leucocyte antigen (DLA) merupakan salah satu faktor genetik yang menyebabkan kasus tumor pada anjing ras Springer spaniel dengan melihat ekspresi polymorphic exon-2 pada lokus II. Hasil identifikasi ini menunjukkan adanya hubungan antara haplotipe dari Major Histocompatibility Complex (MHC) kelas II dan tingkat kejadian tumor pada 363 anjing. Molekul MHC kelas II juga dapat mengindikasikan adanya variasi alel dan haplotipe yang memegang peranan penting sebagai pengindikasi adanya kanker mammae (Hafskjold et al., 2007).

Senyawa aktif buah naga di antaranya antosianin dan betasianin. Antosianin merupakan antioksidan turunan struktur aromatik tunggal, yaitu sianidin, dan semuanya terbentuk dari pigmen sianidin dengan penambahan atau pengurangan gugus hidroksil, metilasi dan glikosilasi antosianin adalah suatu kelas dari senyawa flavonoid yang secara luas terbagi dalam polifenol tumbuhan. Flavonol, flavan-3ol, flavon, flavanon, dan flavanonol adalah kelas dari flavonoid yang berbeda dalam oksidasi antosianin. Senyawa flavonoid tidak berwarna atau kuning pucat. Antosianin termasuk pigmen larut air yang secara alami, terakumulasi pada sel epidermis buah-buahan, akar, dan daun (Harborne, 2005).

Antosianin dapat menekan radikal bebas yang mengandung satu atau lebih elektron yang tidak berpasangan. Senyawa paling berbahaya dalam radikal bebas adalah hidroksil $(\mathrm{OH})$ sebab memiliki reaktivitas paling tinggi. Molekul tersebut sangat reaktif dalam mencari pasangan elektronnya. Jika sudah terbentuk dalam tubuh, maka terjadi reaksi berantai dan menghasilkan radikal bebas baru yang akhirnya membentuk suatu radikal bebas dalam jumlah yang banyak (Wu et al., 2006).

Antioksidan merupakan penangkal radikal bebas. Keberadaan radikal bebas sel menyebabkan timbulnya kanker, gangguan sel saraf, liver, gangguan pembuluh darah seperti jantung koroner, diabetes mellitus, katarak dan penyebab timbulnya proses penuaan dini juga pemicu penyakit kronis. Antosianin merupakan sub-tipe senyawa organik dari keluarga flavonoid, dan merupakan anggota kelompok senyawa yang lebih besar yaitu polifenol. Beberapa senyawa antosianin paling banyak ditemukan adalah pelargonidin, peonidin, sianidin, malvidin, petunidin, dan delfinidin (Cal et al., 2003).
Uji imunohistokimia untuk mengobservasi adanya label antibodi Cox-2 merupakan salah satu cara menganalisis indikasi kanker kelenjar mammae dengan tingkat sensitivitas $96,6 \%$. Peningkatan ekspresi Cox-2 pada sel epitel tubulus asini berhubungan dengan agresivitas penyakit dan peluang proses penyembuhan dari hewan yang menderita kanker kelenjar mammae. Enzim Cox-2 terinduksi pada sel yang mengalami inflamasi oleh sitokin, endotoksin, dan faktor pertumbuhan (growth factors). Peningkatan ekspresi warna label antibodi Cox2 menandakan semakin banyaknya enzim yang tereduksi akibat dari kanker sehingga dapat diketahui tingkat keparahan perubahan patologis (Heller et al., 2005).

\section{SIMPULAN}

Ekstrak etanol kulit buah naga dapat menurunkan indikasi neoplasia kelenjar mammae tikus putih ( $R$. norvegicus) berdasarkan gambaran histopatologi dan inhibitor siklooksigenase-2 (Cox-2).

\section{SARAN}

Penelitian lanjutan perlu dilakukan penelitian dengan ekstrak kulit buah naga dosis minimum untuk mengetahui durasi pengobatan kanker kelenjar mammae stadium III hingga mendekati gambaran organ normal serta dibandingkan dengan hasil terapi teknik radiasi presisi.

\section{UCAPAN TERIMA KASIH}

Penulis mengucapkan terima kasih kepada Lembaga Penelitian dan Inovasi (LPI) Universitas Airlangga dan Program Studi Diluar Kampus Utama (PSDKU) Universitas Airlangga Banyuwangi atas hibah dana sehingga penelitian ini dapat terlaksana dengan baik.

\section{DAFTAR PUSTAKA}

Adams VJ, Evans KM, Sampson J, Wood JLN. 2010. Methods and mortality results of a health survey of pure bred dogs in the UK. J Small Anim Pract 51(10): 512-524.

Cal YZ, Luo Q, Sun M, Corke H. 2003. Antioxidant activity and phenolic coumpounds of 112 traditional chinese: 
Medical Plants Associated with Anticancer. $J$ Life Sci 74: 2157-2184.

Costa C, Soares R, Reis-Filho JS, Leitão D, Amendoeira I, Schmitt FC. 2002. Cyclooxygenase- 2 expression is associated with angiogenesis and lymph node metastasis in human breast cancer. J Clin Pathol 55: 429-434.

Dobson JM. 2013. Breed predispositions to cancer in pedigree dogs. ISRN Vet Sci 2013; Article ID: 941275 .

Evi UU, Amrun MH. 2007. Uji aktivitas antioksidan ekstrak buah naga Hylocereus undatus (Haw) Britt \& Rose. Jurnal Ilmu Dasar 8(1): 83-90.

Hafskjold M, Kennedy LJ, Ollier WER, Catchpole B. 2007. Restricted dog leucocyte antigen (DLA) genotypes in Rotweiler dogs: could this cause poor responses to vaccination. BSAVA Congress. Scientific Proceedings. Hlm.507.

Heller DA, Clifford CA, Goldschmidt MH, Holt DE, Shofer FS, Smith A, Sorenmo KU. 2005. Cyclooxygenase-2 expression is associated with histologic tumor type in canine mammary carcinoma. $J$ Vet Pathol 42: 776 780.

Le Bellec F, Vailant F, Imbert E. 2006. Pithaya : A new fruit crop a market a future. Fruits 61: $237-250$

Kusewitt DF. 2012. Neoplasia and tumor biology. In: Pathologic Basis of Veterinary Disease. McGavin MD, Zachary JF. (Ed). $5^{\text {th }}$. Elsevier. Hlm.289-320.

Misdorp W. 2002. An overview of cancer pathogenesis, diagnosis, and management. In Tumor in Domestic Animals. $4^{\text {th }} \mathrm{Ed}$. Hlm.575-578
Purnama MTE, Samik A. 2014. Potensi Mycotoxin Binders Terhadap Gambaran Histopatologi Neoplasia Kelenjar Mammae Mencit (Mus musculus) Bunting yang Terpapar Zearalenon. Veterinaria 7(1).

Sinuhaji I, Siregar B, Lisnawati. 2013. Ekspresi p16 ${ }^{\mathrm{INK} 4 \mathrm{~A}}$ pada Karsinoma Serviks Usia Muda. Departemen Patologi Anatomik. Fakultas Kedokteran Universitas Indonesia. Jakarta. J Indo Med Assoc 63:1.

Stintzing FC, Schleber A, Carle R. 2003. Evaluation of colour properties and chemical quality parameters of cactus juices. Trends in Food Sci \& Tech 15: 19-38.

Van Dijk JE, Gruys E, Mouwen JMVM. 2008. Color atlas of veterinary pathology. $2^{\text {nd }} \mathrm{Ed}$. Saunders Elsevier. Hlm.177-181.

Warshawsky S, Landolph JR. 2006. Molecular carcinogenesis and the molecular biology of human cancer. $1^{\text {st }}$ Ed. Boca Raton USA, Taylor \& Francis Group. Hlm. 6.

Wu LC, Hsu HW, Chen YC, Chiu CC, Lin YI, Annie JH. 2006. Antioxidant and antiproliferative activities of red pitaya. Food Chem 95: 319-327.

Yang M, Koo SI, Song WO, Chun OK. 2011. Review: Food matrix affecting anthocyanin bioavailability. Curr Med Chem 18(2): 291300.

Yi Y, Wu X, Wang Y, Ye WC, and Zhang QW. 2011. Studies on the flavonoids from the flowers of Hylocereus undatus. $J$ Chinese Med Materials 34(5): 712-716. 